\title{
University-Industry Knowledge Transfer: Channels of Sport Research Interaction
}

\author{
Noni Zaharia ${ }^{1}$ \\ ${ }^{1}$ Erivan K. Haub School of Business, Saint Joseph's University, Philadelphia, PA, USA \\ Correspondence: Dr. Noni Zaharia, Erivan K. Haub School of Business, Saint Joseph's University, 5600 City \\ Avenue, Philadelphia, PA 19131, USA. E-mail: czaharia@sju.edu
}

Received: July 20, 2017

Accepted: August 7, 2017

Online Published: August 12, 2017

doi:10.5539/ijbm.v12n9p1

URL: https://doi.org/10.5539/ijbm.v12n9p1

\begin{abstract}
The reputation of academic programs is increasingly defined in terms of both the generation of high-quality research and the success in transferring scientific findings into commercial development. However, there is a lack of empirical evidence on the particular channels of research interaction between sport academia and sport companies. The purpose of this study was to assess, for the first time, the degree to which different channels of research interaction could be used to inform the research involvement levels of sport organizations with sport academia. Information was gathered from 292 sport managers working for United States sport companies. The results provide evidence that sport managers who collaborated with sport management academia are more concerned with working on joint research projects with sport management scholars and departments than with academic engagement in patenting and licenses, or involvement in networking, scholars' mobility, and publication research channels.
\end{abstract}

Keywords: intellectual property, joint projects, sport industry, sport academia, research collaboration

\section{Introduction}

\subsection{The Problem}

It is broadly recognized that universities and industries are converging toward a hybrid arrangement where the differences between scholarly and commercial rationales are becoming indistinct (e.g., Levy, Roux, \& Wolff, 2009). However, a limited number of firms utilize universities as a supplier of information and knowledge (Laursen \& Salter, 2004; Welsh, Glenna, Lacy, \& Biscotti, 2008). Furthermore, the tendency to collaborate in research with universities differs across industries (Laursen \& Salter, 2004; Levy et al., 2009).

According to Plunkett Research (2015), the estimated size of the entire United States (U.S.) sports industry in 2016 was predicted to be $\$ 498.4$ billion, making it one of the top ten largest industries in the U.S. Despite the size of the sports industry, there is little grant money available for sport management research (Costa, 2005; Mahony, 2008; Stotlar, 2002). Concurrently, sport management academia (i.e., a field concerned with the coordination of the production and marketing of sport services [Chelladurai, 2009]) attempts to understand the role of sports as a societal institution and its potential functions to various sectors of the society (Chalip, 2006; Zhang, 2015). In light of these developments, a number of scholars and professional organizations have promoted collaboration between sport management academics and the sport industry (e.g., Bowers, Green, \& Seifried, 2014; Chelladurai, 1992; Costa, 2005; European Association for Sport Management [EASM], 2012; Inglis, 2007; Irwin \& Ryan, 2013; North American Society for Sport Management [NASSM], 2013; Sport Management Association of Australia and New Zealand [SMAANZ], 2009; Weese, 1995).

Although much has been said of the growing interest for research collaborations among sport management academia and industry, there are few, if any, studies that have examined channels of research interaction (i.e., various scholarly interactions between firms and academia) through which the sport industry communicates with academia. Research from other academic fields suggests that firms draw benefits from universities via rich and varied channels of interaction (Cohen, Nelson, \& Walsh, 2002): From inter-organizational relationships (e.g., joint research or contract research), to face-to-face and short-term interactions (e.g., sport conferences and networking), and to spin-off companies and intellectual property transfer (I.P.; i.e., creations of the mind, such as inventions), including patenting and licensing (D'Este \& Patel, 2007). In addition, almost all U.S. universities 
maintain technology transfer offices to facilitate the commercialization of research, and channels of research interaction such as patents and licenses based on academic discoveries had a 187 billion dollars impact on U.S. gross domestic product alone during the 1997 - 2007 period (Etzkowitz, 2008).

Based on a lack of empirical research that addresses the research gap between sport industry and sport management academia, this study sought to assess, for the first time, the degree to which different channels of research interaction could be used to inform the research involvement levels of U.S. sport organizations with sport academia (i.e. research collaborations with sport management academia, research collaborations with academia other than sport management academia, and no research collaborations with academia).

\subsection{Defining Key Concepts}

To avoid possible confusion, concepts that are central to the perspective developed in this article are defined in this section. These concepts are I.P., patenting, licensing, joint research projects, sustained competitive advantage, and resources.

I.P. embodies unique work reflecting someone's creativity (e.g., inventions, literary and artistic works, designs; U.S. Department of State, n.d.). Patenting, a form of I.P., is a limited monopoly whereby the patent holder is granted the exclusive right to make, use, and sell the patented innovation for a limited period of time in the U.S. and its territories (U.S. Department of State, n.d.). Licensing is the granting of permission to use I.P. rights, such as trademarks, patents, or technology, under defined conditions (U.S. Department of State, n.d.). Joint research projects involve formal research agreements under which original research is conducted in industry - university collaborations (D'Este \& Patel, 2007). Sustained competitive advantage is a strategy implementation that cannot be duplicated by a company's current or potential competitors (Barney, 1991). Resources include all assets, capabilities, information, knowledge, etc. controlled by a firm that enables the firm to conceive of and implement strategies that improve its efficiency and effectiveness (Barney, 1991).

\section{Literature Review}

\subsection{Industry-Academia Research Collaboration}

Over the past decades, universities have developed as economic actors in their own right, which has been important in determining the nature of the collaboration between universities and firms (Bruneel, D'Este, \& Salter, 2010). Collaboration here is defined as an intentional, inter-organizational relationship created to benefit partners and, ultimately, the stakeholders that these partners serve (Bailey \& Koney, 2000). Various professional, economic, social, and political factors encourage industry-academia research collaboration. According to the resource-based view, which contends that the possession of strategic resources provides an organization with a golden opportunity to develop sustainable competitive advantages over its rivals, research collaboration allows for the exchange of new and complementary knowledge and skills that cannot be transmitted through market-based transactions (Barney, 1991). In the transaction cost theory, which supposes that companies try to minimize the costs of exchanging resources with the environment, collaboration helps reduce opportunism and the risk for the transaction (Williamson, 1975). Importantly, these two theories are not mutually exclusive; they are to some extent complementary (Tsang, 2000; Wang, 2007). Research suggests that the most effective way to create research collaborations is by increasing complementary resources and by reducing transaction costs (e.g., Brouthers \& Hennart, 2007; Ou, Varriale, \& Tsui, 2012). Therefore, the transaction cost theory (Williamson, 1975) and the resource-based view (Barney, 1991) can inform industry-academia research collaboration.

To further aid industry-academia research collaborations, policy-makers employed laws that provided commercialization incentives to universities by conferring them ownership of I.P. arising from their research. Examples include the Bayh-Dole Act in the U.S. and similar laws in other countries (Valentin \& Jensen, 2007). The U.S. model was institutionalized in 1980 by an amendment to the Patent and Trademark Law, the Bayh-Dole Act, through which the U.S. Congress turned over to universities intangible I.P. arising from federally-supported academic research. The Bayh-Dole Act took into account the need to incentivize all participants to simultaneously advance commercialization and maximize access to knowledge created with government funds (Etzkowitz, 2008). Some other factors which support research collaborations between the industry and academia are the increased value of (science-based) knowledge and information, the increased costs of scientific equipment, and the insufficient government funding (Rahm, Kirkland, \& Bozeman, 2000). Academic researchers also suggested as research collaboration factors diminish costs of travel and of communication, accompanied by growing availability and easy access, and the growing importance of interdisciplinary fields, that the most significant scientific advances come about due to the integration or 'fusion' of previously separate fields (Katz \& Martin, 1997). 
Sport academia highlighted the importance of interdisciplinary research, and disapproved the silo-mentality that can be present in the sport management academic field (Chalip, 2006; Costa, 2005; Doherty, 2012; Mahony, 2008). One of the potential problems between industry-university research collaborations is that the two groups can have diverging agendas and differing priorities regarding the dissemination of research findings (e.g., Welsh et al., 2008). These potential problems can also be related with sport management academia. To exemplify, sport scholars are worried that the academic dialogue among them maintains the distinction between theory and practice (Costa, 2005; Irwin \& Ryan, 2013), and that the sport management theory building may not be useful to sport managers (Chalip, 2006; Fink, 2013; Newman, 2014). However, it seems that U.S. sport companies and their sport managers do not have a trust or a research relevance issue, but more of a transactional issue when collaborating with sport management academia (Zaharia \& Kaburakis, 2016). Therefore, finding the right research publications or locating the appropriate sport scholars inside a university, or knowing the costs (i.e., time or money costs) related to cooperating with sport management academia, are important transactional contributors in bridging the research collaboration gap between the sport management academia and the sport industry (Zaharia \& Kaburakis, 2016). Nevertheless, despite the sport research progress on explaining research barriers, a gap still exists in the understanding of industry-university channels of research interaction (Chalip, 2006; Costa, 2005; Irwin \& Ryan, 2013; Parks, 1992; Welty Peachey \& Cohen, 2016).

\subsection{Channels to Industry-Academia Research Collaboration}

Collaboration is characterized by two distinct elements: stage and integration. The stage of the collaboration process assumes that partner groups will pass through predictable stages prior to effective collaboration and performance (i.e., assemble, order, perform, and transform; Bailey \& Koney, 2000). Regarding collaboration's integration, there are several levels of integration occurring among organizations, such as affiliations, federations, associations, coalitions, consortia, networks, I.P. collaborations, joint ventures, joint publications, mergers, consolidations, and acquisitions (Bailey \& Koney, 2000). The integration stage in collaboration is in accordance with what this manuscript conveys by the denotation of channels of interaction. Moreover, there are substantial synergies among these channels of academia-industry interaction: while casual face-to-face and short-term interactions may not require a formalized-contractual relationship, they are crucial to improving the effectiveness of formal, long-term research agreements (Kogut, 2000). Therefore, engagement in a wider range of interaction channels with universities may enable the convergence of attitudes between the two parties in the exchange, helping to overcome misalignments due to distinct institutional norms (Cassiman, Guardo, \& Valentini, 2010; Schartinger, Rammer, Fischer, \& Frohlich, 2002).

One channel of industry-academia research interaction is the I.P. channel via patent ownership agreements and via income streams from licenses and royalties which bring billions of dollars per year to the U.S. economy (Etzkowitz, 2008). The resource-based theory explains I.P. channels as an exchange of two resources between firms. These two resources are proprietary resources (i.e., patents, licenses, etc.) and financial resources (i.e., monetary compensation; Yasuda \& Iijima, 2004). I.P. channels are formed if firms, with their financial resources available, need proprietary resources owned by partners (e.g., universities), while the partners prefer to receive financial compensation in exchange for their proprietary resources (Yasuda, 2005). On the other hand, the transaction cost theory explains that firms enter into the I.P. arrangement if monetary compensation for the patents/licenses is lower than the cost incurred developing their own patents/licenses. If firms develop certain patents on their own, it requires investing in costs such as materials, facilities, researchers, and administration. If the sum of such investments required for their own developments exceeds the compensation required for patents, the latter is chosen by firms as the cost-minimizing approach (Yasuda, 2005).

University-industry links embrace a much broader spectrum of activities than just I.P. To exemplify, industry groups have recognized the value of engaging in partnerships with academic institutions via joint research projects. Likewise, the resource-based view suggests that the success of joint ventures depends on the creation or acquisition of complementary resources that are valuable, rare, non-tradable, and difficult to imitate and substitute (Barney, 1991; Das \& Teng, 2000). In addition, Peng (2001) focused on the aspect of organizational learning from the resource-based view and showed that learning from partners represents a primary motivation for firms to enter into joint collaborations. On the other hand, based on the perspective of transaction cost theory, joint projects will be preferred when the transaction costs associated with an exchange are intermediate and not high enough to justify vertical integration (i.e., when a company expands its business into areas that are at different points on the same production path, such as when a manufacturer owns its supplier and/or distributor; Das \& Teng, 2000).

Further, universities supply knowledge to the industry through publications and through human resources mobility and training programs by means of graduates and staff that bring tacit information with them to their 
new jobs (i.e., delivering strategic resources according to the resource-based view; De Fuentes \& Dutrénit, 2012; Etzkowitz, 2008). The transaction cost theory suggests that academic publications and university graduates will be preferred when the transaction cost for companies will be lower than in-house publications/promotions. Sá and Litwin (2011) reviewed the policy mix to foster university-academia collaboration and found that these programs provide incentives for interaction by increasing the networking between the two players (e.g., conferences, workshops, alumni organizations, professional organizations, etc.). Similarly, the resource-based view indicates that the fundamental motivation is the need for additional resources that cannot be purchased via market transactions but are available from scholars met at conferences, workshops, etc. In comparison, the transaction cost theory implies that firms need to economize transaction costs through the use of scholars met at conferences, workshops, etc. (Bekkers \& Bodas-Freitas, 2008). To reiterate, the most effective way to create means for research interactions is by increasing complementary resources and by reducing transaction costs (e.g., Brouthers \& Hennart, 2007; Ou, Varriale, \& Tsui, 2012). Thus, both these theories can be used when explaining the choice of channels of research interaction between industry and academia.

Sport scholars have also suggested potential channels of research interaction to bridge the gap with the sport industry. Sport academics focused for example on action research, a form of investigation undertaken by scholars and then used by practitioners in decision-making (Gerrard, 2015; Inglis, 2007), or on having a joint sport management database that can be used by the industry (Mahony, 2008; Zeigler, 2007). Some other possible avenues of channels of research interaction can be publishing in trade journals (Stotlar \& Braa, 2012; Sutton, 2012), or the creation of a non-profit association via the major sport companies to address research issues (King, 2013). As noted by Chelladurai (2009), the establishment of professional associations is an indication of the maturity of a profession. It represents the coming together of collective ideas from both practitioners and scholars to generate guidelines of self-regulation for those in the profession.

Parks (1992), and Irwin and Ryan (2013) proposed that professors could implement a merger of theory and practice through the scholarship of application by sending their students into the field of sport management equipped with the most recent knowledge and expertise, and serving as consultants to various segments of the sport industry. Faculty who actively engage in consulting with sport organizations believe that those activities keep them grounded and provide real-life examples to enhance both teaching and learning (Stotlar \& Braa, 2012). Sport academic researchers also suggested working for U.S. sport organizations during a faculty sabbatical (Sutton, 2012). Other answers proposed by sport scholars about the collaboration problem include establishing a practically-oriented sport management journal (Cuneen \& Parks, 1997; Weese, 1995), and attending and presenting papers at the sport industry's professional meetings where scholars and practitioners gather to disseminate the best thinking in both theory and practice (Cuneen \& Parks, 1997; Sutton, 2012).

As different industries have different knowledge bases and innovation patterns (e.g. Asheim \& Coenen, 2005), they also employ different channels of interacting in research with academia. However, there is a lack of empirical evidence on the particular channels of research interaction used by sport organizations in their collaboration with academia.

\section{Method}

\subsection{Participants and Data Collection}

Survey data were collected in the form of web-based questionnaires. The survey link was disseminated to people who held a managerial position in the U.S. sport industry, as past research recognized that real users and developers of knowledge in the industry are better positioned to answer questions about industry-academia research collaboration (Bekkers \& Bodas Freitas, 2010; Cohen et al., 2002). A message containing a link to a web-based survey was distributed via email to the surveyed subjects. In the message and in the survey, individuals were asked whether they were making managerial decisions in their organizations, as past research clearly states that all managers are decision-makers (i.e., persons who apply knowledge resulting in the selection of a belief or a course of action among several alternative possibilities; Pugh \& Hickson, 2007; Vroom, 1973).

The sample consisted of 18,206 email addresses and was randomly selected from two different online sport databases, Team Marketing Report FactBook and Street \& Smith's Sports Business Resource Guide. One of the databases consisted of more than 70,000 North American sport executives ("SportsBusiness Journal," n.d., para. 2), and the other contained more than 4,200 contacts of key sport decision makers in the U.S. ("Team Marketing Report," n.d., para. 2). These sport executives and decision makers were included in these two databases by U.S. sport companies, when the latter were asked to provide key executive contacts for their organizations.

After checking for bounce-back, incorrect, invalid or double email addresses, this figure was adjusted to 11,714. No survey reminders were sent, and the questionnaire remained active for 10 weeks, at which time a total of 357 
surveys were collected. Incorrect information and deletion of outliers eliminated 65 surveys, which resulted in 292 usable surveys. The researchers then addressed the non-response error, as one of the main functions of survey research is to generalize findings back to a larger population (Jordan, Walker, Kent, \& Inoue, 2011). One of the strategies for handling non-response error is to compare early to late respondents on core study variables (Jordan et al., 2011; Miller \& Smith, 1983). Although the response rate of $2.49 \%$ was low, the early wave of participants and the late wave of participants revealed no significant differences in terms of the mean scores of 29 out of the 34 initial variables, collectively suggesting that there was no significant non-response bias. Further, there are a lot of professionals and companies who still keep email addresses on file without those emails bouncing back (e.g., automated email replies such as: "please use my new address," etc). Unfortunately, the employed survey software had no way of informing the researchers about these email addresses' inadvertencies. Also, one need to keep in mind that most surveyed participants were executive contacts, who normally have little time and a flurry of emails in their inbox. Using t-tests and chi-square analyses to compare variable means, only gender $\left(\chi^{2}(1, N=100)=6.83, p=.009\right)$, university or other educational organization $\left(\chi^{2}(1, N=100)=5.12, p\right.$ $=.023)$, professional sport teams sub-sector $\left(\chi^{2}(1, N=100)=15.41, p<.001\right)$, sport marketing/advertising/PR sub-sector $\left(\chi^{2}(1, N=100)=7.11, p=.008\right)$, and college sports sub-sector $\left(\chi^{2}(1, N=100)=4.34, p=.037\right)$ were found to have significant differences between early and late survey respondents, and could pose difficulties on their generalization to a larger population (Jordan et al., 2011; Miller \& Smith, 1983).

The data indicated that $34.60 \%(n=101)$ of the 292 respondents had been involved through their sport companies in collaborative research with sport management academia, and 50.70\% $(n=148)$ did not collaborate in research with universities, while the remaining respondents $(n=43)$ teamed up in research endeavors with universities' departments other than the sport management field. The sample covered a diverse range of firms, with representation from organizations of different sizes and regions, across many sport industry's sub-sectors. Sample demographics are available in Table 1.

Table 1

Demographic Characteristics of U.S. Respondents and Their Sport Organizations

\begin{tabular}{|c|c|c|c|}
\hline \multicolumn{2}{|l|}{ Demographic variable } & \multicolumn{2}{|l|}{ Demographic variable } \\
\hline Gender & & Organization Establishment Period & \\
\hline Male $(\%)$ & 82.20 & Before $1980(\%)$ & 52.70 \\
\hline Female $(\%)$ & 17.80 & Between 1980 and $1999(\%)$ & 34.90 \\
\hline Age & & In 2000 or later $(\%)$ & 12.40 \\
\hline $18-34(\%)$ & 18.50 & Organization Type & \\
\hline $35-44(\%)$ & 22.30 & Small ( $<100$ employees) $(\%)$ & 48.30 \\
\hline $45-54(\%)$ & 32.50 & Medium (100 - 500 employees) (\%) & 31.50 \\
\hline 55 or over $(\%)$ & 26.70 & Large ( $>500$ employees) $(\%)$ & 8.90 \\
\hline Education & & University or other educational organization (\%) & 11.30 \\
\hline Less than High School (\%) & 0.00 & Industry Sub-Sector & \\
\hline High School or Some College (\%) & 5.80 & College Sports (\%) & 15.80 \\
\hline College Degree $(\%)$ & 47.90 & Professional Sport Service Providers and Facilities (\%) & 7.20 \\
\hline Masters Degree (\%) & 37.70 & Professional Sport Teams (\%) & 40.30 \\
\hline Doctoral or Professional Degree (\%) & 8.60 & Sport Governing Bodies (\%) & 5.50 \\
\hline Organization Location & & Sport Marketing/Advertising/P.R. (\%) & 8.60 \\
\hline North-East Region (\%) & 18.50 & Sports Media (\%) & 7.20 \\
\hline Mid-West Region (\%) & 18.80 & Other $(\%)$ & 15.40 \\
\hline West Region (\%) & 25.70 & Sector & \\
\hline South Region (\%) & 37.00 & Public (\%) & 29.50 \\
\hline & & Private $(\%)$ & 70.50 \\
\hline
\end{tabular}

\subsection{Measures}

The questionnaire was comprised of three sections. Survey respondents were asked in the first section to indicate their company's research collaboration level with academia. The study considered the research collaboration level as a dependent variable with three categories, each representing occurrences of sport academia research 
engagement: Collaboration with sport management academia, collaboration with departments other than sport management academia, and no collaboration with universities (coded 1, 2, and 3, respectively). In the second section the participants were invited to specify their level of agreement with 23 statements concerning some likely channels of research interaction with universities where a survey instrument modeled after Bekkers and Bodas Freitas (2008) was used. Respondents were asked to rate the importance of each channel of research interaction, using the following categories: 0: 'Not used', 1: 'Of very little importance', 2: 'Of little importance', 3: 'Important', 4: 'Very important'. In addition, the attentiveness of participants was tested by inserting in this section the statement "On this question please click on 'Very important' so we can ensure you are paying attention," accounting for measurement error, a possible survey error that needs to be minimized to improve survey estimates (Dillman, Smyth, \& Christian, 2014). Furthermore, in the third section the research included a range of demographic factors of sport industry's managers and their companies as control variables. These control variables were included as they might have an influence on the level of research collaborations between firms and universities, and were collected as dummy variables, per the recommended procedures (Cohen, Cohen, West, \& Aiken, 2003). To exemplify, in past studies of industry-university links, researchers have examined the impact of firm size on industry-university collaboration (e.g., Levy et al., 2009). Most of the findings suggested that big companies invest more in research with universities and have more human resources dedicated to this task than other types of firms. Also, start-ups are more likely to collaborate with universities (Cohen et al., 2002; Fontana, Geuna, \& Matt, 2006). In addition, several studies suggested that the geographical proximity of firms and universities is associated with increased research spending from firms (e.g., Laursen, Reichstein, \& Salter, 2011); however, different sectors and industrial environments have dissimilar factors that allow industry-university collaborations (Laursen \& Salter, 2004). Practitioners' motivations for channels of engaging with sport academia and the control variables constituted the research's explanatory variables. For a full list of items tested, see Table 4.

\subsection{Data Analysis}

Data were analyzed using SPSS 21, AMOS 21, and Stata 12. Before any analyses were conducted, the normality of the data was assessed. Moreover, independent variables were checked for multicollinearity. Then, to assess the measurement model, a confirmatory factor analysis (CFA) was conducted. Internal consistency of the constructs was measured through composite reliability (CR; Hair, Black, Babin, \& Anderson, 2009). Convergent validity was evaluated through the average variance extracted (AVE), while discriminant validity was established when AVE for each construct exceeded the squared correlations between that and any other construct (Fornell \& Larcker, 1981). Goodness of fit for the measurement model was assessed with the ratio of chi-square $\left(\chi^{2}\right)$ to its degrees of freedom, Tucker-Lewis Index (TLI), comparative-of-fit-index (CFI), goodness-of-fit index (GFI), and root mean square error of approximation (RMSEA).

Next, the results from the CFA and the control variables were statistically analyzed in Stata 12 by using a multinomial logit regression analysis in order to assess which channel of research interaction would explain the research engagement level of U.S. sport organizations with the sport academia. Because this paper used a dependent variable with three different categories (i.e., research collaborations with the sport management academia, research collaborations with academia other than sport management academia, and no research collaborations with academia), this study utilized a multinomial logit model, which permits the analysis of decisions across more than two categories in the dependent variable. The "no research collaboration with academia" category served as the reference group, because the reference group should act as a useful comparison and the baseline group should not have a small sample size relative to the other groups (Cohen et al., 2003).

Furthermore, Kline (2005) suggested that a factor analysis needs a sample size of at least 200, thus the sample size of 292 was sufficient for a CFA. Spicer (2005) proposed that a minimum sample size of 100 is needed to establish a logit regression model; therefore, this study's sample size is adequate for a multinomial logit regression.

\section{Results}

Multivariate outliers were identified with the use of Mahalanobis $D^{2}$ measure. Hair and colleagues (2009) recommend a conservative threshold of $p<.001$ for the multivariate outlier test. Eleven cases were removed based on multivariate outlier detection, where both $p$-values of the Mahalanobis $D^{2}$ equaled .000 . Furthermore, all independent variables were checked for multicollinearity using bivariate correlations. All correlation coefficients were far below the suggested threshold of .9 (Tabachnick \& Fidell, 2007).

\subsection{Measurement Model}

The results of the CFA in the model showed that the standardized factor loadings ranged from .55 to .97 and were all significant $(p<.001)$, hence surpassing the cut-off point of .50 (Hair et al., 2009). As shown in Table 2, 
all the CR values ranged from .76 to .93 , indicating acceptable levels of reliability for the constructs, according to the recommended .70 threshold (Hair et al., 2009). Moreover, all AVE values were equal or greater than the .50 standard for convergent validity (Fornell \& Larcker, 1981), ranging from .51 to .82 , and thus, indicating acceptable levels of convergent validity for the constructs. In addition, discriminant validity of the measures was accepted given that the AVE for each construct is greater than the squared correlation between the construct and other constructs in the model (Fornell \& Larcker, 1981). Table 3 lists additional descriptive statistics (i.e., mean and standard deviations) and the correlation matrix for the constructs, with the correlations among constructs and the square root of AVE on the diagonal. The three diagonal elements of the latent variables were all larger than their corresponding correlation coefficients, which indicated that the metrics had appropriate discriminant validity.

\section{Table 2}

Factor Loadings, Composite Reliability (CR), and Average Variance Extracted (AVE)

\begin{tabular}{|c|c|c|c|}
\hline Constructs/items & Loading $^{\mathrm{b}}$ & $\mathrm{CR}$ & AVE \\
\hline Networking Channels $^{\text {a }}$ & & .76 & .51 \\
\hline Participation of sport management faculty at conferences and workshops that you attend & .818 & & \\
\hline Personal (informal) contacts with sport management faculty & .692 & & \\
\hline Personal contacts via alumni organizations & .627 & & \\
\hline Intellectual Property Channels ${ }^{\mathrm{a}}$ & & .93 & .82 \\
\hline Sport management/marketing patent texts, as found in the patent office or patent databases & .969 & & \\
\hline $\begin{array}{l}\text { Licenses of university-held sport management/marketing patents and 'know-how' licenses } \\
\text { Specitic sport knowledge transter activities organized by the university's 'Technology 'Transfer Ottice }\end{array}$ & $\begin{array}{l}.970 \\
.769\end{array}$ & & \\
\hline Scholars Mobility Channels ${ }^{\mathrm{a}}$ & & .79 & .56 \\
\hline Inflow of university graduates as employees (Ph.D. level) & .629 & & \\
\hline Statt holding positions in both a university and a business & .796 & & \\
\hline Temporary staff exchange with universities (e.g., staff mobility programs) & .805 & & \\
\hline Joint Projects Channels ${ }^{\mathrm{a}}$ & & .91 & .76 \\
\hline Joint research projects with sport academia & .795 & & \\
\hline Joint research contracts with sport academia & .961 & & \\
\hline Consultancy from sport academia & .857 & & \\
\hline Publications Channels ${ }^{\mathrm{a}}$ & & .78 & .55 \\
\hline Scientific sport management publications in journals or books & .825 & & \\
\hline Other sport management publications, including professional publications and reports & .546 & & \\
\hline Sport management/marketing case studies from academic journals or books & .824 & & \\
\hline
\end{tabular}

Table 3

Mean (M), Standard Deviation (SD), and Correlation Matrix

\begin{tabular}{|c|c|c|c|c|c|c|c|}
\hline & & & & rrelat & $\mathrm{n} M$ & & \\
\hline Variables & $\mathrm{M}$ & SD & $\overline{1}$ & 2 & 3 & 3 & 5 \\
\hline 1. Networking Channels & 2.39 & .86 & .72 & & & & \\
\hline 2. Intellectual Property Channels & .95 & 1.04 & .37 & .91 & & & \\
\hline 3. Scholars Mobility Channels & 1.46 & .99 & .50 & .67 & .75 & & \\
\hline 4. Joint Projects Channels & 1.46 & 1.08 & .45 & .63 & .73 & .87 & \\
\hline 5. Publications Channels & 2.09 & .87 & .46 & .49 & .49 & .61 & .74 \\
\hline
\end{tabular}

Note:

Diagonals in bold are square root of AVE.

In accordance with the aim of the study, the first step was to ensure that the CFA model was reasonable and a good fit in the full sample $(N=292)$. The model showed an acceptable fit to the data after dropping eight items which demonstrated poor factor loadings, $\chi^{2}(78)=162.391, p<.001, \chi^{2} / \mathrm{df}=2.082$, TLI $=.96$, CFI $=.97$, GFI 
$=.93$, RMSEA $=.061$. Although the chi-square goodness of fit index was statistically significant, in general, chi-square-based statistics can be misleading (Schumacker \& Lomax, 2010). Also, the ratio of the chi-square to its degrees of freedom was within the 3.0 criteria (Kline, 2005). The values for the additional fit indices exceeded the critical values for good model fit, as CFI, TLI and GFI values higher than .90 are considered to have a close fit (Hair et al., 2009). In addition, the RMSEA value was within the criteria of .08 indicating an acceptable fit (Byrne, 2010).

\subsection{Multinomial Logit Regression Analysis}

The constructs from CFA and the control variables were statistically analyzed by using a multinomial logit regression analysis. Moreover, per the recommended procedures of regression analyses, each categorical variable with more than two levels was assigned a reference group (Cohen et al., 2003).

As with any fitted model there is a need to assess its overall fit and examine the contribution of each variable to the fit (Hosmer \& Lemeshow, 2000). The likelihood ratio chi-square test to measure goodness of fit was significant, $\chi^{2}(54)=108.82, p<.001$, which indicated that the full model did predict significantly better, or more accurately, than the null model. Additionally, the Independence of Irrelevant Alternatives hypothesis was not violated based on the Hausman-type test (Hausman \& McFadden, 1984). The dependent variable defined 18.75\% of the variance in independent variables according to McFadden value (McFadden, 1974), and the overall classification results indicated that the model correctly classified $56.80 \%$ of the research involvement levels of U.S. sport organizations with academia.

The "no research collaboration with academia" category served as the baseline group, but this meant that the significance and sign of the coefficient needed to be interpreted relative to this category. Instead, the researchers chose to discuss the marginal effects of the explanatory variables on the probabilities of each research collaboration level, since marginal effects will greatly simplify the analysis (Cameron \& Trivedi, 2009; Gallié \& Roux, 2010). Marginal effects can be interpreted as the effect on the conditional mean of the dependent variable of a change in one of the independent variables (Cameron \& Trivedi, 2009). A full representation on marginal effects of the multinomial logit regression analysis can be viewed in Table 4.

The probability of choosing the "research collaborations with sport management academia" category was significantly reduced by a decline in joint project channels $(d y / d x=.178, p<.001)$ between sport academia and the sport industry, and by an increase in I.P. channels between sport academia and industry $(d y / d x=-.099, p$ $=.004)$. Furthermore, respondents between the ages of 18 and 34 years old $(d y / d x=.205, p=.020)$ and 35 and 44 years old $(d y / d x=.171, p=.029)$ had a significantly higher probability of engaging in research collaborations with sport academia than did the sport executives or professional researchers who were 55 years old or older. Also, the sport marketing/advertising/PR companies had a significantly higher probability of engaging in research collaborations with sport academia than professional sport teams $(d y / d x=.195, p=.039)$. Plus, sport managers who held a Masters degree had a significantly higher probability of getting involved in research collaborations with non-sport management academia than the ones who held a bachelor degree $(d y / d x=.128, p$ $=.006)$.

The probability of choosing the "no research collaborations with academia" category was significantly reduced by an increase in joint project channels between sport academia and the sport industry $(d y / d x=-.195, p<.001)$, and by a decline in I.P. channels between sport academia and the sport industry $(d y / d x=.144, p<.001)$. Further, respondents between the ages of 35 and 44 years old $(d y / d x=-.172, p=.027)$ and between the ages of 45 and 54 years old $(d y / d x=-.179, p=.009)$ had a significantly lower probability to not engage in research collaborations with universities than did the sport executives or professional researchers who were 55 years old or older. Also, sport managers who held a doctoral degree or a professional degree (i.e., J.D. or M.D.) had a significantly lower probability to not collaborate in research cooperation with academia than the ones who held a bachelor degree $(d y / d x=-.207, p=.044)$. Finally, sport service providers and sport facilities $(d y / d x=.285, p$ $=.010$ ) had a significantly higher probability to not collaborate in research cooperation with academia compared to professional sport teams. 
Table 4

Multinomial Logit Regression Results of U.S. Research Collaboration Categories: Marginal Effects

\begin{tabular}{|c|c|c|c|}
\hline Variables & Category 1 & Category 2 & Category 3 \\
\hline Networking Channels & .071 & -.009 & -.062 \\
\hline Intellectual Property Channels & $-.099 *$ & -.045 & $.144 * *$ \\
\hline Scholars Mobility Channels & -.007 & .021 & -.014 \\
\hline Joint Projects Channels & $.178 * *$ & .017 & $-.195 * *$ \\
\hline Publications Channels & .016 & .021 & -.038 \\
\hline Sector (public/private) & .030 & .083 & -.113 \\
\hline Gender & .051 & .001 & -.052 \\
\hline \multicolumn{4}{|l|}{ Age } \\
\hline $18-34$ & $.205 *$ & -.112 & -.093 \\
\hline $35-44$ & $.171 *$ & .001 & $-.172 *$ \\
\hline $45-54$ & .128 & .051 & $-.179 *$ \\
\hline \multicolumn{4}{|l|}{55 or over (reference) } \\
\hline \multicolumn{4}{|l|}{ Education } \\
\hline High school or some college & -.041 & -.031 & .072 \\
\hline \multicolumn{4}{|l|}{ College degree (reference) } \\
\hline Masters degree & -.015 & $.128 *$ & -.113 \\
\hline Doctoral or professional degree & .105 & .102 & $-.207 *$ \\
\hline \multicolumn{4}{|l|}{ Organization Location } \\
\hline \multicolumn{4}{|l|}{ North-East region (reference) } \\
\hline Mid-West region & -.029 & -.050 & .079 \\
\hline West region & .014 & -.047 & .034 \\
\hline South region & .010 & -.090 & .080 \\
\hline \multicolumn{4}{|l|}{ Organization Establishment Period } \\
\hline \multicolumn{4}{|l|}{ Before 1980 (reference) } \\
\hline Between 1980 and 1999 & -.039 & .031 & .008 \\
\hline In 2000 or later & -.071 & .007 & .065 \\
\hline \multicolumn{4}{|l|}{ Organization Type } \\
\hline \multicolumn{4}{|l|}{ Small ( $<100$ employees) (reference) } \\
\hline Medium (100 - 500 employees) & .038 & -.026 & -.012 \\
\hline Large ( $>500$ employees) & -.048 & .116 & -.067 \\
\hline Educational firms & -.041 & -.018 & .059 \\
\hline \multicolumn{4}{|l|}{ Industry Sub-Sector } \\
\hline Professional sport service providers and facilities & -.147 & -.137 & $.285 *$ \\
\hline \multicolumn{4}{|l|}{ Professional sport teams (reference) } \\
\hline Sport governing bodies & .112 & -.146 & .035 \\
\hline Sport marketing/advertising/PR & $.195 *$ & -.074 & -.120 \\
\hline Sport media & .070 & -.219 & .149 \\
\hline College sports & .099 & -.018 & -.081 \\
\hline Other & .051 & -.088 & .037 \\
\hline
\end{tabular}

\section{Note:}

Categories: 1 = "Research collaboration with sport management academia," 2 = "Research collaboration with academia other than sport management academia," 3 = "No research collaboration with academia." For binary coded variables, the result expresses the impact of a discrete change of the variable from 0 to 1 . Significant at: $* p<.05 ; * * p<.001$

\section{Discussion and Implications}

Research interactions between sport management academia and firms may contribute to innovation and production-related benefits for firms and intellectual and economic benefits for sport scholars (e.g., Bowers et al., 2014; Chelladurai, 1992; Irwin \& Ryan, 2013; NASSM, 2013; SMAANZ, 2009; Weese, 1995). From this study's results, it is clear that several types of interaction affect research collaborations between the U.S. sport industry and sport management academia, such as research channels, industry sub-sectors, and age and education level of the surveyed participants.

The multinomial logit regression analysis revealed that the I.P. channels variable was a significant predictor of research collaborations. The findings suggest that U.S. sport firms reported significantly lower I.P. research channels in their collaboration with sport management academia than U.S. sport companies that did not 
collaborate with universities, in line with previous research from other industries (Cohen et al., 2002; D'Este \& Patel, 2007). Therefore, sport management patents and licenses, and other sport knowledge transfer activities organized by a university's Technology Transfer Office, may be less frequently exploited by firms in their collaboration with sport management academia, presumably because only a minority of university-industry interactions is motivated by the prospect of directly-realized inventions or commercial products (e.g., D'Este \& Patel, 2007). Moreover, it seems that there are few specific inventions or products originating from sport management academia because the field is still young (e.g., Chalip, 2006; Doherty, 2012). Also, in many cases, faculty do not disclose inventions to their university (Siegel, Waldman, \& Link, 2003), plus there is an unrealistic expectation from universities in regard to the feasibility and extent of commercial exploitation opportunities for university research (Clarysse, Wright, Lockett, Mustar, \& Knockaert, 2007). Using the resource-based view and the transaction cost theory, considering that I.P. research channels do not often lead to sustainable competitive advantages and that the effort/cost of firms to link through these I.P. channels of research interaction far outweigh the benefits obtained from it (Agrawal \& Henderson, 2002; D'Este \& Patel, 2007), sport firms may not be too enticed to collaborate with sport management academia on I.P. research channels.

However, even before talking about the potential of sustained competitive advantages and/or lowering transaction costs through I.P. research channels between sport academia and the sport industry, sport scholars and administrators need to understand that currently there are no I.P. research channels incentives regarding acquiring tenure for professors as, for example, patents are not taken into account for academic scholarship (Sanberg et al., 2014). Considering that academic scholarship is one of the main objectives of sport scholars to acquire tenure and promotion (Cuneen \& Parks, 1997), there can be little motivation to pursue I.P. research channels in the first place. Also, an invention needs to show the potential for commercial success before universities will seek I.P. protection for that invention (e.g., Shane, 2004). Therefore, sport management departments will need to inform the outside environment about their range of technical and scientific capability in order to attract potential partners and open up new channels of research interaction (e.g., I.P. research channels).

On the other hand, respondents who collaborated with sport management academia conveyed significantly higher joint projects research interaction channels than the ones who did not collaborate with academia. Thus, these results provide evidence that the U.S. sport managers who collaborated with sport management academia are more concerned with working on joint research projects with sport management scholars and departments than with academic engagement in patenting and knowledge transfer licenses. Researchers from other academic fields highlighted that, for most industries, patents and licenses were less important than channels for conveying research through consulting and joint research agreements (e.g., Agrawal \& Henderson, 2002; Cohen et al., 2002; Schartinger et al., 2001). In fact, joint research channels may be the most effective way to convey novelty and therefore to allow innovation progress (e.g., De Fuentes \& Dutrénit, 2012). Danylchuk and Boucher (2003) report that sport management academicians indicated that creating research channels/partnerships with sport business professionals represented one of the most influential measures toward advancing the discipline. In addition, Stotlar and Braa (2012) and Zhang (2015) acknowledged that the academy and its sport management scholars may face tenacious challenges if the institution cannot provide the joint research that garners grant support and research funding.

Moreover, compared to research projects individually undertaken by firms, cooperative research projects are thought to reduce research time, costs, and associated risks by sharing them with research partners (Gallié \& Roux, 2010). Also, joint projects are competitive strategies to gain market share or to build entry barriers (Oxley \& Sampson, 2004). It may also be a matter of a shortage of skills that leads firms to joint research projects, as Sutton (2012) reasoned that sport scholars have more training in research methods and statistics than most sport industry professionals and will meaningfully contribute to solving sport industry problems. Therefore, the surveyed participants could have noticed an increase of competitive advantages (e.g., grow market share through sport industry - academia joint research projects) and a reduction of transaction costs (e.g., reduced research time) in their research collaborations with sport academia, in line with what Irwin and Ryan (2013) theorized about the benefits of the university-industry research collaboration in sport management. Still, research based on joint projects usually requires confidentiality from academic scholars, and this interferes with fundamental academic principles (e.g. the universality of knowledge) that have supported scientific thought and progress (Martin, 2000). Thus, the main disincentive to this type of research for sport faculty is the difficulty in meeting academic goals, especially journal publications (Gerrard, 2015; King, 2013). Moreover, Zaharia and Kaburakis (2016) acknowledged that a potential solution for this type of problem will depend on having practice academics or professors of practice to bridge the gap in research with the industry by emphasizing the potential of sustained 
competitive advantages and/or low transaction costs incurred by joint research projects, as currently sport academia's tenure requirements do not usually include research collaborations with the industry.

Networking channels, scholars' mobility channels, as well as publication channels were not found to be significant in this paper on all three levels of research collaboration and were not in agreement with previous research from other countries and industries (e.g., Dutrénit, De Fuentes, \& Torres, 2010; Orozco \& Ruiz, 2010). These results provide evidence that U.S. sport managers who did collaborate with sport management academia are more concerned with working on joint research projects with sport academia than with meeting sport faculty at conferences they attend, accepting staff to hold positions in both a university and a business, or examining sport management academic publications. Considering that the content of these channels (e.g., networking channels, scholars' mobility channels, publication channels) is mostly defined by the conventional roles of universities (i.e., teaching, research, and service), sport scholars can grow professionally by pursuing these research channels with the industry, despite the practitioners' apparent characterization of such channels as lower priority.

To illustrate, it is important to understand that the primary avenues for the expression of sport scholarship are scholarly journals and professional associations (e.g., Cuneen \& Parks, 1997). However, the findings of sport management academic journals may not even reach the industry (King, 2013; Newman, 2014; Stotlar \& Braa, 2012; Zeigler, 2007). Sport management academic articles may be attending to a narrow audience, while the goal of fostering knowledge transfer with the industry is to make scholarly research accessible to as many people as possible, free of cost, compared with the present situation of traditional, limited-access academic journals (Adler \& Harzing, 2009). Currently there is a proliferation of broader dissemination options in the sport management academic field with highly-selective scholarly journals, such as Journal of Sport Management (JSM) and Sport Management Review (SMR), which allow sport scholars the paid option of having their articles published open-access (i.e., without financial, legal, or technical barriers, other than those inseparable from gaining access to the Internet itself; "JSM open access," para. 1; "SMR guide for authors," n.d., para. 14). Taking into account that the most effective way to create research collaborations is by increasing complementary resources and by reducing transaction costs (e.g., Brouthers \& Hennart, 2007; Ou, Varriale, \& Tsui, 2012), and considering the transaction cost theory of Williamson (1975), the study's findings suggest that indeed there can be transaction-cost problems due to open-access restrictions. Furthermore, as per the resource-based view, companies will achieve a sustained competitive advantage if such resources are, for example, valuable in the sense that they exploit opportunities and/or neutralize threats in a firm's environment (Barney, 1991). Yet, sport practitioners may perceive sport academic research as having little value because managers consider academic scholarship irrelevant to their work (e.g., Fink, 2013; Miller, 2012; Newman, 2014; Welty Peachey \& Cohen, 2016), or sport practitioners do not identify the value related to cooperating with sport management academia in the first place because of transactional barriers, such as finding the right sport research publications or locating the right sport scholars inside a university (Zaharia \& Kaburakis, 2016).

Other distinctive findings point out that younger generations of U.S. organizations' sport managers have a more favorable view toward collaboration with sport management academia, in line with the university-industry collaborations from other academic fields (e.g., Fernandes et al., 2010), while respondents possessing a graduate education (i.e., Master, Ph.D., J.D., and M.D.) had a significant tendency to collaborate in research with academia, compared with those who held bachelor's degrees. Likewise, greater appreciation for rigorous sport research is transmitted to the field through well-informed graduates entering the workforce (Irwin \& Ryan, 2013; Miller, 2012; Parks, 1992). Thus, it appears that sport professionals with a graduate education are likely to be more familiar with university norms and research compared to sport professionals with only undergraduate degrees. Another interesting finding from this study is that sport marketing/advertising/PR firms had a higher probability of collaborating with sport academia than professional sport teams and professional sport service providers and facilities. This could be a matter of research interests, as sport marketing is one of the most important areas of sport scholarly research (Ciomaga, 2013; Dittmore, Mahony, Andrew, \& Phelps, 2007); thus, sport marketing companies may be enticed to connect in research with sport marketing scholars. Lastly, sport companies' size, location, sector, and year when a sport organization was founded did not significantly impact sport management research collaborations, in contrast with findings from other academic fields (e.g., Cohen et al., 2002; Levy et al., 2009).

There is plenty of evidence that universities can make important contributions to improving the economic performance of firms and attending to social needs in both developed and developing countries due to the increase of programs that promote research cooperation between firms and universities (Bekkers \& Bodas-Freitas, 2008; Cassiman et al., 2010; Cohen et al., 2002; Welty Peachey \& Cohen, 2016). This study's 
results highlight the current relevance of joint projects' research channels between the sport industry and sport management academia. The overall findings should provide guidance for professional and academic administrators when designing arrangements that prioritize certain channels of research interaction. Essentially, by paying greater attention to the broad range of channels of research interaction, academic policy initiatives could contribute to aligning sport researchers' skills with industry needs, and pursue processes necessary to integrate the worlds of scientific research and application.

\section{Limitations and Future Research}

First, sport management academia's perceptions and connections with the sport industry should be examined in order to provide a more complete picture on sport industry-academia research interactions. Second, this research did not explicitly address respondents whose organizations collaborated with both sport management academia and other academic departments, because this specific collected sample was negligible in this paper. Thus, researchers can account for this variable in subsequent studies. Third, while this research was developed within the U.S. context, it might not be applicable to other countries. Therefore, researchers should test these findings in more countries where the sport industry and academia have experienced growth, such as Canada, Australia, China, the United Kingdom, and mainland Europe. Fourth, the current study examined only the regional location of the surveyed organizations. Future research should take into account the distance between firms and sport management academic programs in order to determine whether geographic proximity promotes industry-academia research interactions (Laursen et al., 2011). Fifth, while this research analyzed important industry-academia collaboration variables, it did not measure the R\&D intensity of analyzed companies. Past authors have found that firms which invest highly in R\&D are more prone to interact with universities (e.g., Fontana et al., 2006), while others noticed no significant relationship between R\&D intensity and cooperation (e.g., Lopez, 2008). Sixth, future studies should also take into account whether organizations that did collaborate were frequent or infrequent partners with universities, or what type of collaboration (formal, informal, etc.) was undertaken. Seventh, there is the possibility that the survey was completed by more than one individual from the same organization; however, confidentiality of the data had to be preserved by having anonymous subjects. Eighth, although the researchers drew information from multiple sport organizations, the study focused on one period, which makes it difficult to draw inferences about the direction of causality. Future research should explore the channels of research interaction over time, and examine the factors that increased or lowered the probability to utilize certain channels of research interaction. For example, it may be that new strategic changes in sport organizations will have an impact on the employed channels of research interaction.

\section{References}

Adler, N. J., \& Harzing, A. W. (2009). When knowledge wins: Transcending the sense and nonsense of academic rankings. Academy of Management Learning \& Education, 8(1), 72-95. https://doi.org/10.5465/AMLE.2009.37012181

Agrawal, A., \& Henderson, R. (2002). Putting patent in context: Exploring knowledge transfer at MIT. Management Science, 48(1), 44-60.

Asheim, B. T., \& Coenen, L. (2005). Knowledge bases and regional innovation systems: Comparing Nordic clusters. Research Policy, 34, 1173-1190. https://doi.org/10.1287/mnsc.48.1.44.14279

Bailey, D., \& Koney, K. M. (2000). Strategic alliances among health and human services organizations: From affiliations to consolidations. Thousand Oaks, CA: Sage Publications.

Barney, J. (1991). Firm resources and sustained competitive advantage. Journal of Management, 17(1), 99-120.

Bekkers, R., \& Bodas Freitas, I. M. (2008). Analysing knowledge transfer channels between universities and industry: To what degree do sectors also matter? Research Policy, 37, 1837-1853.

Bekkers, R., \& Bodas Freitas, I. M. (2010, June). Catalysts and barriers: Factors that affect the performance of university-industry collaborations. Paper presented at the 13th International Schumpeter Society conference, Aalborg, Denmark.

Bowers, M. T., Green, B. C., \& Seifried, C. S. (2014). Let the marketplace be the judge: The founders reflect on the origins and trajectory of NASSM. Journal of Sport Management, 28, 565-587.

Brouthers, K. D., \& Hennart, J. F. (2007). Boundaries of the firm: Insights from international entry mode research. Journal of Management, 33, 395-425.

Bruneel, J., D'Este, P., \& Salter, A. (2010). Investigating the factors that diminish the barriers to university-industry collaboration. Research Policy, 39, 858-868. 
Byrne, B. M. (2010). Structural equation modeling with AMOS: Basic concepts, applications, and programming. New York: Routledge.

Cameron, A. C., \& Trivedi, P. K. (2009). Microeconometrics using Stata. College Station, TX: Stata Press.

Cassiman, B., Di Guardo, M. C., Valentini, G., (2010). Organizing links with science: Cooperate or contract? A project-level analysis. Research Policy, 39, 882-892.

Chalip, L. (2006). Toward a distinctive sport management discipline. Journal of Sport Management, 20(1), 1-21. https://doi.org/10.1123/jsm.20.1.1

Chelladurai, P. (1992). Sport management: Opportunities and obstacles. Journal of Sport Management, 6, 215-219. https://doi.org/10.1123/jsm.6.3.215

Chelladurai, P. (2009). Managing organizations for sport and physical activity: A systems perspective. Scottsdale, AZ: Holcomb Hathaway, Publishers, Inc.

Ciomaga, B. (2013). Sport management: A bibliometric study on central themes and trends. European Sport Management Quarterly, 13, 557-578. https://doi.org/10.1080/16184742.2013.838283

Clarysse, B., Wright, M., Lockett, A., Mustar, P., \& Knockaert, M. (2007). Academic spin-offs, formal technology transfer and capital raising. Industrial and Corporate Change, 16, 609-640.

Cohen, J., Cohen, P., West, S. G., \& Aiken, L. S. (2003). Applied multiple regression/correlation analysis for the behavioral sciences. Mahwah, NJ: Lawrence Erlbaum Associates, Inc.

Cohen, W. M., Nelson, R. R., \& Walsh, J. P. (2002). Links and impacts: The influence of public research on industrial R\&D. Management Science, 48(1), 1-23.

Costa, C. A. (2005). The status and future of sport management: A Delphi study. Journal of Sport Management, $19,117-142$.

Cuneen, J., \& Parks, J. B. (1997). Should we serve sport management practice or sport management education? A response to Weese's perspective. Journal of Sport Management, 11, 125-132.

D'Este, P., \& Patel, P. (2007). University-industry linkages in the UK: What are the factors underlying the variety of interactions with industry? Research Policy, 36, 1295-1313.

Danylchuk, K. E., \& Boucher, R. (2003). The future of sport management as an academic discipline. International Journal of Sport Management, 4, 281-300.

Das, T. K., \& Teng, B. S. (2000). A resource-based theory of strategic alliances. Journal of Management, 26(1), 31-61.

De Fuentes, C., \& Dutrénit, G. (2012). Best channels of academia-industry interaction for long-term benefit. Research Policy, 41, 1666-1682.

Dillman, D. A., Smyth, J. D., \& Christian, L. M. (2014). Internet, phone, mail, and mixed-mode surveys: The tailored design method. Hoboken, NJ: John Wiley \& Sons.

Dittmore, S. W., Mahony, D. F., Andrew, D. P. S., \& Phelps, S. (2007). Is sport management research diverse? A five-year analysis of dissertations. International Journal of Sport Management, 8(1), 21-31.

Doherty, A. (2012). "It takes a village:" Interdisciplinary research for sport management. Journal of Sport Management, 27(1), 1-10.

Dutrénit, G., De Fuentes, C., \& Torres, A. (2010). Channels of interaction between public research organisations and industry and their benefits: Evidence from Mexico. Science and Public Policy, 37, 513-526.

Etzkowitz, H. (2008). The triple helix: University-industry-government innovation in action. New York, NY: Routledge. https://doi.org/10.4324/9780203929605

European Association for Sport Management. (2012). The European for Sport Management brochure. Retrieved from http://easm.net/easmbackup/wp-content/uploads/2013/01/2012-brochure.pdf

Fernandes, A. C., de Souza, B. C., da Silva, A. S., Suzigan, W., Chaves, C. V., \& Albuquerque, E. (2010). Academy-industry links in Brazil: Evidence about channels and benefits for firms and researchers. Science and Public Policy, 37, 485-498.

Fink, J. S. (2013). Theory development in sport management: My experience and other considerations. Sport Management Review, 16(1), 17-21. 
Fontana, R., Geuna, A., \& Matt, M. (2006). Factors affecting university-industry R\&D projects: The importance of searching, screening and signalling. Research Policy, 35, 309-323.

Fornell, C., \& Larcker, D. F. (1981). Evaluating structural equation models with unobservable variables and measurement error. Journal of Marketing Research, 18(1), 39-50.

Gallié, E. P., \& Roux, P. (2010). Forms and determinants of R\&D collaborations: Evidence based on French data. Industry and Innovation, 17, 551-576.

Gerrard, B. (2015). Rigour and relevance in sport management: Reconciling the competing demands of disciplinary research and user-value. European Sport Management Quarterly, 15, 505-515. https://doi.org/10.1080/16184742.2015.1085714

Hair, J. F., Jr., Black, W. C., Babin, B. J., \& Anderson, R. E. (2009). Multivariate data analysis. Upper Saddle River, NJ: Prentice Hall.

Hausman, J., \& McFadden, D. (1984). Specification tests for the multinomial logit model. Econometrica: Journal of the Econometric Society, 52, 1219-1240.

Hosmer, D., \& Lemeshow, S. (2000). Applied logistic regression. New York: Wiley-Interscience Publication.

Inglis, S. (2007). Creative tensions and conversations in the academy. Journal of Sport Management, 21(1), 1-14. https://doi.org/10.1123/jsm.21.1.1

Irwin, R. L., \& Ryan, T. D. (2013). Get real: Using engagement with practice to advance theory transfer and production. Sport Management Review, 16(1), 12-16.

Jordan, J. S., Walker, M., Kent, A., \& Inoue, Y. (2011). The frequency of nonresponse analyses in the Journal of Sport Management. Journal of Sport Management, 25, 229-239.

Journal of Sport Management. (n.d.). Open access. Retrieved from http://journals.humankinetics.com/open-access-jsm

Katz, J. S., \& Martin, B. R. (1997). What is research collaboration? Research Policy, 26(1), 1-18.

King, B. (2013, August 12). Can academic research help sports industry? SportsBusiness Journal. Retrieved from http://www.sportsbusinessdaily.com/Journal/Issues/2013/08/12/In-Depth/Sports-business-professors.aspx

Kline, R. B. (2005). Principles and practice of structural equation modeling. New York: The Guilford Press.

Kogut, B. (2000). The network as knowledge: Generative rules and the emergence of structure. Strategic Management Journal, 21, 405-425.

Laursen, K., \& Salter, A. (2004). Searching high and low: What types of firms use universities as a source of innovation? Research Policy, 33, 1201-1215.

Laursen, K., Reichstein, T., \& Salter, A. (2011). Exploring the effect of geographical proximity and university quality on university-industry collaboration in the United Kingdom. Regional Studies, 45, 507-523.

Levy, R., Roux, P., \& Wolff, S. (2009). An analysis of science-industry collaborative patterns in a large European university. The Journal of Technology Transfer, 34(1), 1-23.

Lopez, A. (2008). Determinants of R\&D cooperation: Evidence from Spanish manufacturing firms. International Journal of Industrial Organization, 26(1), 113-136. https://doi.org/10.1016/j.ijindorg.2006.09.006

Mahony, D. F. (2008). No one can whistle a symphony: Working together for sport management's future. Journal of Sport Management, 22(1), 1-10. https://doi.org/10.1123/jsm.22.1.1

Martin, M. (2000). Managing university-industry relations: A study of institutional practices from 12 different countries. Paris, France: UNESCO, International Institute of Educational Planning.

McFadden, D. (1974). Conditional logit analysis of qualitative choice behavior. In Zarembka, P. (Eds.), Frontiers in econometrics (pp. 105-142). New York: Academic Press.

Miller, J. (2012). Publish or perish? In Gillentine, A., Baker, R. \& Cuneen, J. (Eds.), Critical essays in sport management: Exploring and achieving a paradigm shift (pp. 84-93). Scottsdale, AZ: Holcomb Hathaway, Publishers, Inc.

Miller, L. E., \& Smith, K. L. (1983). Handling nonresponse issues. Journal of Extension, 21(5), 45-50.

Newman, J. I. (2014). Sport without management. Journal of Sport Management, 28, 603-615.

North American Society for Sport Management. (2013). Constitution of the North American Society for Sport 
Management. Retrieved from http://www.nassm.com/files/NASSM\%20Constitution\%20June\%202013.pdf

Orozco, J., \& Ruiz, K. (2010). Quality of interactions between public research organisations and firms: Lessons from Costa Rica. Science and Public Policy, 37, 527-540. https://doi.org/10.3152/030234210X512034

Ou, A. Y., Varriale, L., \& Tsui, A. S. (2012). International collaboration for academic publication: Implications from the resource-based view and transaction cost theory. Group \& Organization Management, 37, 407-451. https://doi.org/10.1177/1059601112448422

Oxley, J. E., \& Sampson, R. C. (2004). The scope and governance of international R\&D alliances. Strategic Management Journal, 25, 723-749.

Parks, J. B. (1992). Scholarship: The other "bottom line" in sport management. Journal of Sport Management, 6, 220-229. https://doi.org/10.1123/jsm.6.3.220

Peng, M. W. (2001). The resource-based view and international business. Journal of Management, 27, 803-829.

Plunkett, J. W. (2015). Plunkett's Sports Industry Almanac 2016. Houston, TX: Plunkett Research, Limited.

Pugh, D. S., \& Hickson, D. J. (2007). Great writers on organizations. Burlington, VT: Ashgate Publishing, Ltd.

Rahm, D., Kirkland, J., \& Bozeman, B. (2000). University-industry R\&D collaboration in the United States, the United Kingdom, and Japan. Dordrecht, Netherlands: Springer Science \& Business Media.

Sá, C. M., \& Litwin, J. (2011). University-industry research collaborations in Canada: The role of federal policy instruments. Science and Public Policy, 38, 425-435. https://doi.org/10.3152/030234211X12960315267732

Sanberg, P. R., Gharib, M., Harker, P. T., Kaler, E. W., Marchase, R. B., Sands, T. D., ... \& Sarkar, S. (2014). Changing the academic culture: Valuing patents and commercialization toward tenure and career advancement. Proceedings of the National Academy of Sciences, 111, 6542-6547.

Schartinger, D., Rammer, C., Fischer, M., Frohlich, J. (2002). Knowledge interactions between universities and industry in Austria: Sectoral patterns and determinants. Research Policy, 3, 303-328.

Schumacker, R. E., \& Lomax, R. G. (2010). A beginner's guide to structural equation modeling. New York: Routledge.

Shane, S. (2004). Encouraging university entrepreneurship? The effect of the Bayh-Dole Act on university patenting in the United States. Journal of Business Venturing, 19(1), 127-151.

Siegel, D. S., Waldman, D., \& Link, A. (2003). Assessing the impact of organizational practices on the relative productivity of university technology transfer offices: An exploratory study. Research Policy, 32(1), 27-48.

Spicer, J. (2005). Making sense of multivariate data analysis: An intuitive approach. Thousand Oaks, CA: Sage Publications, Inc. https://doi.org/10.4135/9781412984904

Sport Management Review. (n.d.). Guide for authors. Retrieved from https://www.elsevier.com/journals/sport-management-review/1441-3523/guide-for-authors

Sport Management Society of Australia and New Zealand. (2009). Constitution and operating charter. Retrieved from http://www.smaanz.org/docs/SMAANZConstitution.pdf

SportsBusiness Journal. (n.d.). Frequently asked questions. Retrieved from http://www.sportsbusinessdaily.com/RG-Live/Search/FAQs.aspx

Stotlar, D. K. (2002). A decade of evolution: The sport industry. Sport Marketing Quarterly, 11(1), 55-58.

Stotlar, D. K., \& Braa, L. L. (2012). Theory versus practice: A balancing act. In Gillentine, A., Baker, R. \& Cuneen, J. (Eds.), Critical essays in sport management: Exploring and achieving a paradigm shift (pp. 71-83). Scottsdale, AZ: Holcomb Hathaway, Publishers, Inc.

Sutton, W. A. (2012). Academia and the sports industry: An auto-ethnography, pracademics, and a collaborative model. In Gillentine, A., Baker, R. \& Cuneen, J. (Eds.), Critical essays in sport management: Exploring and achieving a paradigm shift (pp. 115-124). Scottsdale, AZ: Holcomb Hathaway, Publishers, Inc.

Tabachnick, B. G., \& Fidell, L. S. (2007). Using multivariate statistics. Boston, MA: Pearson Education.

Team Marketing Report. (n.d.). What is the sports sponsor factbook? Retrieved from https://www.teammarketing.com/btSubscriptions/subscriptions?sState=username\%3D

Tsang, E. W. (2000). Transaction cost and resource-based explanations of joint ventures: A comparison and synthesis. Organization Studies, 21(1), 215-242. 
U.S. Department of State. (n.d.). What is intellectual property (IP)? Retrieved from http://www.state.gov/e/eb/tpp/ipe/what/

Valentin, F., \& Jensen, R. (2007). Effects on academia-industry collaboration of extending university property rights. Journal of Technology Transfer, 32, 251-276. https://doi.org/10.1007/s10961-006-9015-x

Vroom, V. H. (1973). A new look at managerial decision making. Organizational Dynamics, 1(4), 66-80.

Wang, Y. (2007). Managerial choice between equity joint ventures and contractual joint ventures in China: A critical test of transaction cost economics and resource-based view. Asian Business \& Management, 6, $355-375$.

Weese, W. J. (1995). If we're not serving practitioners, then we're not serving sport management. Journal of Sport Management, 9, 237-243. https://doi.org/10.1123/jsm.9.3.237

Welsh, R., Glenna, L., Lacy, W., \& Biscotti, D. (2008). Close enough but not too far: Assessing the effects of university-industry research relationships and the rise of academic capitalism. Research Policy, 37, 1854-1864. https://doi.org/10.1016/j.respol.2008.07.010

Welty Peachey, J., \& Cohen, A. (2016). Research partnerships in sport for development and peace: Challenges, barriers, and strategies. Journal of Sport Management, 30(3), 282-297.

Williamson, O. E. (1975). Markets and hierarchies: Antitrust analysis and implications. New York: The Free Press.

Yasuda, H. (2005). Formation of strategic alliances in high-technology industries: Comparative study of the resource-based theory and the transaction-cost theory. Technovation, 25, 763-770.

Yasuda, H., \& Iijima, J. (2004). Analytical framework of strategic alliances from the perspective exchange of management resources. International Journal of Business Performance Management, 6(1), 88-105.

Zaharia, N., \& Kaburakis, A. (2016). Bridging the gap: U.S. sport managers on barriers to industry-academia research collaboration. Journal of Sport Management, 30(3), 248-264.

Zeigler, E. F. (2007). Sport management must show social concern as it develops tenable theory. Journal of Sport Management, 21, 297-318. https://doi.org/10.1123/jsm.21.3.297

Zhang, J. J. (2015). What to study? That is a question: A conscious thought analysis. Journal of Sport Management, 29(1), 1-10. https://doi.org/10.1123/JSM.2014-0163

\section{Copyrights}

Copyright for this article is retained by the author(s), with first publication rights granted to the journal.

This is an open-access article distributed under the terms and conditions of the Creative Commons Attribution license (http://creativecommons.org/licenses/by/4.0/). 